\title{
Wear and Corrosion Behavior of High-Cr White Cast Iron Alloys in Different Corrosive Media
}

\author{
Kh. Abd El-Aziz ${ }^{1}$ Kh. Zohdy ${ }^{2}$ D. Saber ${ }^{1}$ H. E. M. Sallam ${ }^{1,3}$
}

Received: 15 June 2015/Revised: 5 August 2015/ Accepted: 20 August 2015/Published online: 29 August 2015

(c) Springer International Publishing AG 2015

\begin{abstract}
This study aims to investigate the effect of $\mathrm{Cr} /$ $\mathrm{C}$ ratio on wear and corrosion behavior of a group of high$\mathrm{Cr}$ white cast iron (HCCI) alloys. Three different alloys of HCCI with different chemical compositions were tested against $3.5 \% \mathrm{NaCl}, 0.5 \mathrm{M} \mathrm{H}_{2} \mathrm{SO}_{4}$, and $0.5 \mathrm{M} \mathrm{NaOH}$ solutions as corrosive media. Electrochemical polarization technique has been used to determine the corrosion current density. The microstructure characteristics of HCCI alloys were analyzed by using optical microscope, SEM, EDS, and XRD. XRD analysis reveals that the microstructure of the HCCI alloys is composed of a network of chromiumrich carbides $\left(\mathrm{M}_{7} \mathrm{C}_{3}\right)$ in an austenitic matrix. The abrasive wear resistance of HCCI alloys was found to be rely on their chemical composition and microstructure. The corrosion resistance of the HCCI alloys strongly depends on the $\mathrm{Cr} / \mathrm{C}$ ratio and the ratio of chromium content in the $\mathrm{M}_{7} \mathrm{C}_{3}$ carbide to that in the matrix $\left(\mathrm{CrM}_{7} \mathrm{C}_{3} /\right.$ Matrix $)$. The experimental results of this study showed that the alloy HCCI-2 with the lower $\mathrm{Cr} / \mathrm{C}$ ratio exhibited the lowest
\end{abstract}

H. E. M. Sallam

hem_sallam@yahoo.com

Kh. Abd El-Aziz

khalid_elaziz@yahoo.com

Kh. Zohdy

drkhaledzohdy@yahoo.com

D. Saber

daliasaber13@yahoo.com

1 Materials Engineering Department, Zagazig University, Zagazig 44519, Egypt

2 Chemical Engineering Department, Higher Tech. Institute, 10th of Ramadan, Egypt

3 Civil Engineering Department, Jazan University, Jazan 82822-6694, Saudi Arabia abrasive wear loss while the alloy HCCI-1 with higher $\mathrm{Cr}$ / $\mathrm{C}$ ratio exhibited the highest abrasive wear loss. On the other hand, the HCCI-1 alloy was the most corrosion resistant and revealed the lowest current density. In addition, the corrosion current density of all specimens is elevated in $0.5 \mathrm{M} \mathrm{H}_{2} \mathrm{SO}_{4}$ solution in comparison with $3.5 \mathrm{wt} \%$ $\mathrm{NaCl}$ and $0.5 \mathrm{M} \mathrm{NaOH}$ solutions.

Keywords Abrasive wear behavior - High-Cr WCI . Corrosion behavior $\cdot$ Microstructure $\cdot \mathrm{Cr} / \mathrm{C}$ ratio

\section{Introduction}

Many engineering applications require materials with excellent resistance to both corrosion and wear [1-7]. High-Cr white cast irons have excellent wear and corrosion resistance and are inexpensive, and thus have been used for impact coal crusher hammers, pulverizer rings, chute liner, and hardfacing alloys of rolls or molds. The exceptional abrasive and erosive wear resistance results primarily from the presence of high volume fraction of very hard eutectic carbides in a strong supporting matrix in their microstructure. The carbides presented in the $\mathrm{Fe}-\mathrm{Cr}-\mathrm{C}$ system are $(\mathrm{Fe}, \mathrm{C})_{3} \mathrm{C}, \quad(\mathrm{Fe}, \mathrm{Cr})_{7} \mathrm{C}_{3}, \quad(\mathrm{Fe}, \mathrm{Cr})_{23} \mathrm{C}_{6}$, and $(\mathrm{Fe}, \mathrm{Cr})_{3} \mathrm{C}_{2}$ [2-4]. In many previous studies [4-6], the type and form of eutectic carbides change from $\mathrm{M}_{3} \mathrm{C}$ to $\mathrm{M}_{7} \mathrm{C}_{3}$ with an increase in $\mathrm{Cr}$ content. In unalloyed or low- $\mathrm{Cr}$ white cast irons containing below $5 \% \mathrm{Cr}$ and up to $2 \% \mathrm{C}$, the eutectic carbides of the $\mathrm{M}_{3} \mathrm{C}$ type in a continuous ledeburitic form (with hardness of $\mathrm{HV}=1000$ ) are present. At $8-10 \% \mathrm{Cr}$, the eutectic carbides become less continuous, and fracture resistance is improved. But above $10 \% \mathrm{Cr}$, the form of eutectic carbides changes to the discontinuous $\mathrm{M}_{7} \mathrm{C}_{3}$ type (with hardness of 
$\mathrm{HV}=1200-1800)$. The irons used in high stress abrasion environments must not only be resistant to abrasion, but also have adequate toughness to resist fracture and failure. In the range from 9.5 to $15 \%$ of chromium content, carbides type $(\mathrm{Cr}, \mathrm{Fe})_{7} \mathrm{C}_{3}$ appears, and above $30 \%$ chromium carbides type $(\mathrm{Cr}, \mathrm{Fe}){ }_{23} \mathrm{C}_{6}$ solidifies [4]. Information on the corrosion behavior of alloyed white irons is important in material selection for wear parts, which have to withstand the combined effects of abrasion and corrosion in applications such as wet grinding and slurry transport. While high-alloy white cast irons are primarily for severe abrasion and erosion conditions, they are also demonstrated fair to excellent corrosion resistance in various environments when they contain relatively high levels of chromium and other alloy elements [8]. High-chromium white irons, under ASTM A532 Class-III Type-A, contain 23-30 \% Cr (by weight), and may considerably contain higher weight percent for some special grades used in erosion-corrosion applications. Higher alloy content especially chromium can significantly improve the corrosion resistance of high-Cr white irons to corrosive conditions, such as reducing acids [9]. In many slurry transportation systems, such as chemical processing applications, corrosion and erosion are the two main mechanisms of material degradation of the pump wet-end components including pump casing, impeller, and liners. At relatively high corrosion intensity, the white cast irons with higher alloy content (especially chromium) clearly showed improved corrosion resistance and combined erosion-corrosion resistance over those with lower alloy content. Although Ni-resist irons showed good corrosion resistance to many environments and are frequently used, they lack sufficient mechanical strength and suitability at a service temperatures higher than $\left(800{ }^{\circ} \mathrm{C}\right)$ [10]. Single phase microstructures are most suitable in resisting corrosion for obvious reasons. The effectiveness of a twophase microstructure in resisting corrosion depends on the morphology of the second phase, its volume fraction, the nature of the interface between the matrix and second phase, and the difference in electrochemical potential of the two constituents. For example, in cast irons, the microstructure comprising austenite and carbide is better than those comprising austenite and graphite in resisting corrosion. For better corrosion resistance, second phase particles should be nearly spherical and their volume fraction should be optimum in order to avoid galvanic cell formation and pitting corrosion. The objective of the present research is to study the wear and corrosion behavior of a group of HCCI alloys with different chemical compositions (i.e., $\mathrm{Cr} / \mathrm{C}$ ratios) in $3.5 \% \mathrm{NaCl}, 0.5 \mathrm{M} \mathrm{H}_{2} \mathrm{SO}_{4}$ and $0.5 \mathrm{M} \mathrm{NaOH}$ solutions. The microstructure of the high- $\mathrm{Cr}$ WCI alloys was characterized using optical microscope, SEM, EDS, and XRD.

\section{Experimental Procedure}

\subsection{Materials and Microstructure Examination}

Several HCCI alloys were produced by sand casting technique and melting the appropriate raw materials in an induction furnace. Casting was then performed in bentonite sand molds at the temperature range of $1460-1480{ }^{\circ} \mathrm{C}$. The specimens of wear, corrosion, and metallographic tests were cut from $300 \mathrm{~mm}$ long bars with $23 \mathrm{~mm}$ in diameter by using an abrasive cut-off wheel, mounted, and prepared using conventional techniques. These specimens were of a cylindrical shape with a dimension of $20 \mathrm{~mm}$ in diameter and a length of $20 \mathrm{~mm}$. The chemical compositions of HCCI alloys used in the present study are shown in Table 1. The metallographic specimens were ground (using water proof $\mathrm{SiC}$ abrasive emery papers ranging from 120 to 1200 grit size), polished and chemically etched with $3 \%$ nital solution (3\% nitric acid-97\% ethyl alcohol) to reveal the general microstructure constituents. The etching time varied from a few seconds up to $60 \mathrm{~min}$ for all alloys. The microstructure characteristics of HCCI alloys were analyzed by using optical microscope, SEM, and EDS. The phases presented in HCCI were also determined by XRD. The specimens for $\mathrm{XRD}$ were prepared in the same way as the samples for optical microscope and SEM but were not etched.

\subsection{Abrasive Wear Test}

The chemical composition was mainly based on high carbon contents in order to obtain a good participation of carbides. Chromium was used in amounts $21-24 \%$, since it contributes to the formation of structures with high participation of hard chromium carbides, thus achieving a good wear resistance. The abrasive wear tests were employed to evaluate the wear characteristics of the investigated alloys in. These tests were carried out on the pin-on-disk wear testing machine. Before the test, the specimen ends were roughly ground, polished with $320-1200$ grit size SiC emery paper to remove any scratches or indentations found on their surfaces. The tests were carried out against 120 mesh $\mathrm{SiC}$ (emery paper) abrasives at a $1.04 \mathrm{~m} / \mathrm{s}$ sliding speed and under the normal loads of 20 and $40 \mathrm{~N}$. The total traveling distance was $250 \mathrm{~m}$. The abrasive wear of the alloys was measured by their weight loss. Each value was obtained from an average of at least three measurements.

\subsection{Corrosion Test}

The corrosion behavior of HCCI alloys was studied using potentiodynamic electrochemical technique. The corrosion 
Table 1 Chemical composition of high-Cr WCI alloys used in the present study and corresponding $\mathrm{Cr} / \mathrm{C}$ ratios

\begin{tabular}{|c|c|c|c|c|c|c|c|c|c|c|c|}
\hline \multirow[t]{2}{*}{ Alloy designation } & \multicolumn{10}{|c|}{ Composition (wt $\%$ ) } & \multirow[t]{2}{*}{$\mathrm{Cr} / \mathrm{C}$ ratio } \\
\hline & $\mathrm{C}$ & $\mathrm{Si}$ & $\mathrm{S}$ & $\mathrm{P}$ & $\mathrm{Mn}$ & $\mathrm{Ni}$ & $\mathrm{Cr}$ & Mo & $\mathrm{V}$ & $\mathrm{Fe}$ & \\
\hline HCCI-1 & 1.83 & 0.31 & 0.008 & 0.017 & 0.75 & 0.85 & 23.9 & 0.38 & 0.33 & Bal & 13 \\
\hline HCCI-2 & 3.16 & 1.5 & 0.013 & 0.027 & 0.68 & 0.72 & 22.1 & 0.45 & 0.32 & Bal & 6.98 \\
\hline HCCI-3 & 2.4 & 1.69 & 0.010 & 0.019 & 0.79 & 0.99 & 21 & 0.33 & 0.22 & $\mathrm{Bal}$ & 8.75 \\
\hline
\end{tabular}

test specimens were prepared by grinding and polishing with alumina paste to $3 \mu \mathrm{m}$ finish and cleaned with acetone before the test. Electrochemical tests were conducted in 3.5 wt $\% \mathrm{NaCl}, 0.5 \mathrm{M} \mathrm{H}_{2} \mathrm{SO}_{4}$, and $0.5 \mathrm{M} \mathrm{NaOH}$ solutions prepared prior to each test using distilled water. All electrochemical experiments were conducted with a Gamry PCI300/4 Potentiostat/Galvanostat/Zra analyzer. It was connected to a PC. The Echem Analyst software (version 5.21) was used for all electrochemical data analysis. A three-electrode cell composed of a specimen as a working electrode, platinum counter electrode, and saturated calomel electrode (SCE) as a reference electrode was used in the tests. Tafel polarization tests were carried out using a scan rate of $0.5 \mathrm{mV} / \mathrm{min}$ at $25^{\circ} \mathrm{C}$. Prior to electrochemical tests, the specimens were cathodically cleaned for $15 \mathrm{~min}$ at $-1500 \mathrm{mV}$ (SCE) to remove the air-formed oxide film. The applied routine automatically selects the data that lies within the Tafel region $( \pm 250 \mathrm{mV}$ with respect to the corrosion potential).

\section{Results and Discussion}

\subsection{Microstructure Characterization}

From the optical photomicrographs, the microstructure of HCCI alloys may be observed. It is well documented that the microstructure of all hypo-eutectic HCCI alloys consists of a network of $\mathrm{M}_{7} \mathrm{C}_{3}$ eutectic carbides in a matrix of austenite or its transformation products [11-14]. The optical photomicrographs which illustrate the microstructures of the investigated alloys are shown in Fig. 1. From Fig. 1a, it is clear that the microstructure of the alloy HCCI-1 consists of primary dendritic austenitic matrix in a network of $\mathrm{M}_{7} \mathrm{C}_{3}$ eutectic carbides. The addition of small amounts of Mo (i.e., $0.5 \% \mathrm{Mo}$ ) is sufficient for suppressing pearlite formation when particularly used in combination with other elements such as copper and at a higher $\mathrm{Cr} / \mathrm{C}$ ratio $[15,16]$. According to previous studies [17-19], some martensite may also present in the austenitic structure, predominantly in localized regions adjacent to the eutectic carbides where the depletion of chromium and carbon from the austenite has raised the Ms temperature sufficiently to permit the transformation to martensite. The pearlitic matrix was obtained in the low-Cr white cast iron in the absence of other alloying additions [20]. In Fig. 1b, it is clear that the microstructure of alloy HCCI-2 consists of a network of intermitent- $\mathrm{M}_{7} \mathrm{C}_{3}$ eutectic carbides in austenitic matrix. This micrograph shows the presence of primary hexagonallike morphology of $\mathrm{M}_{7} \mathrm{C}_{3}$ carbides. The microstructure of the alloy HCCI-3 is shown in Fig. 1c. The microstructure of this alloy consists of primary dendritic austenitic matrix in a network of $\mathrm{M}_{7} \mathrm{C}_{3}$ eutectic carbides.

Figure 2 illustrates XRD pattern for HCCI-1 alloy with $\mathrm{Cr} / \mathrm{C}$ ratio of 13 , which demonstrates that the specimens consist of a ferrous austenitic matrix and $\mathrm{M}(\mathrm{Fe}, \mathrm{Cr})_{7} \mathrm{C}_{3}$ carbides. Since the corrosion resistance of HCCI alloys is largely affected by the chemical compositions of the ferrous matrix, concentrations of $\mathrm{Cr}, \mathrm{Fe}, \mathrm{Mn}$, and $\mathrm{Si}$ in the matrix were determined using an energy dispersive X-ray spectrometer (EDS). The microstructural characterization of the HCCI alloys was performed using a scanning electron microscope equipped with an energy dispersive X-ray analyzer (SEM-EDS). Results of the compositional analysis are presented in Fig. 3, which shows SEM/EDS analysis on the microstructure constituents (matrix and carbides) of the alloy HCCI-1. As demonstrated, more $\mathrm{Cr}$ was consumed to form carbides as wt $\% \mathrm{C}$ was increased, resulting a decrease in wt\% $\mathrm{Cr}$ in the matrix. Figures 4 and 5 show the XRD traces and SEM/EDS analysis for the HCCI-2 alloy in the ascast condition. XRD analysis shown in Fig. 4 confirmed the presence of austenitic matrix and $\mathrm{M}_{7} \mathrm{C}_{3}$ carbides and ferrite in the as-cast structure of this alloy. Relevant elements shown in Fig. 5 have been detected, and their wt $\%$ are given quantitively in Table 2 . The results proved that the above microstuctural analysis is reasonable and accurate. This has proved the microstructural changes observed in Fig. 1 for HCCI alloys. Maratray and Usseglio-Nanot [21] proposed an empirical formula to estimate the carbide volume fraction $(\% \mathrm{~K})$ in CWIs. Maratray's expression was as follows:

$\% \mathrm{~K}=12.33 * \operatorname{wt}(\mathrm{C})+0.55 * \mathrm{wt}(\mathrm{Cr})-15.2$,

where; \% $\mathrm{K}, \mathrm{wt}(\mathrm{C})$ and $\mathrm{wt}(\mathrm{Cr})$ represent the volume fraction of carbides, carbon, and chromium, respectively. According to Maratary formula, the carbide volume fraction of HCCI alloys in the present study ranges from 20.5 to $36 \%$. The higher volume fraction of carbides was $36 \%$ for the HCCI-2 alloy and the lower volume fraction was $20.5 \%$ for the HCCI-1 alloy. The volume fraction of the Cr carbides of the alloy HCCI-3 was $26 \%$. 

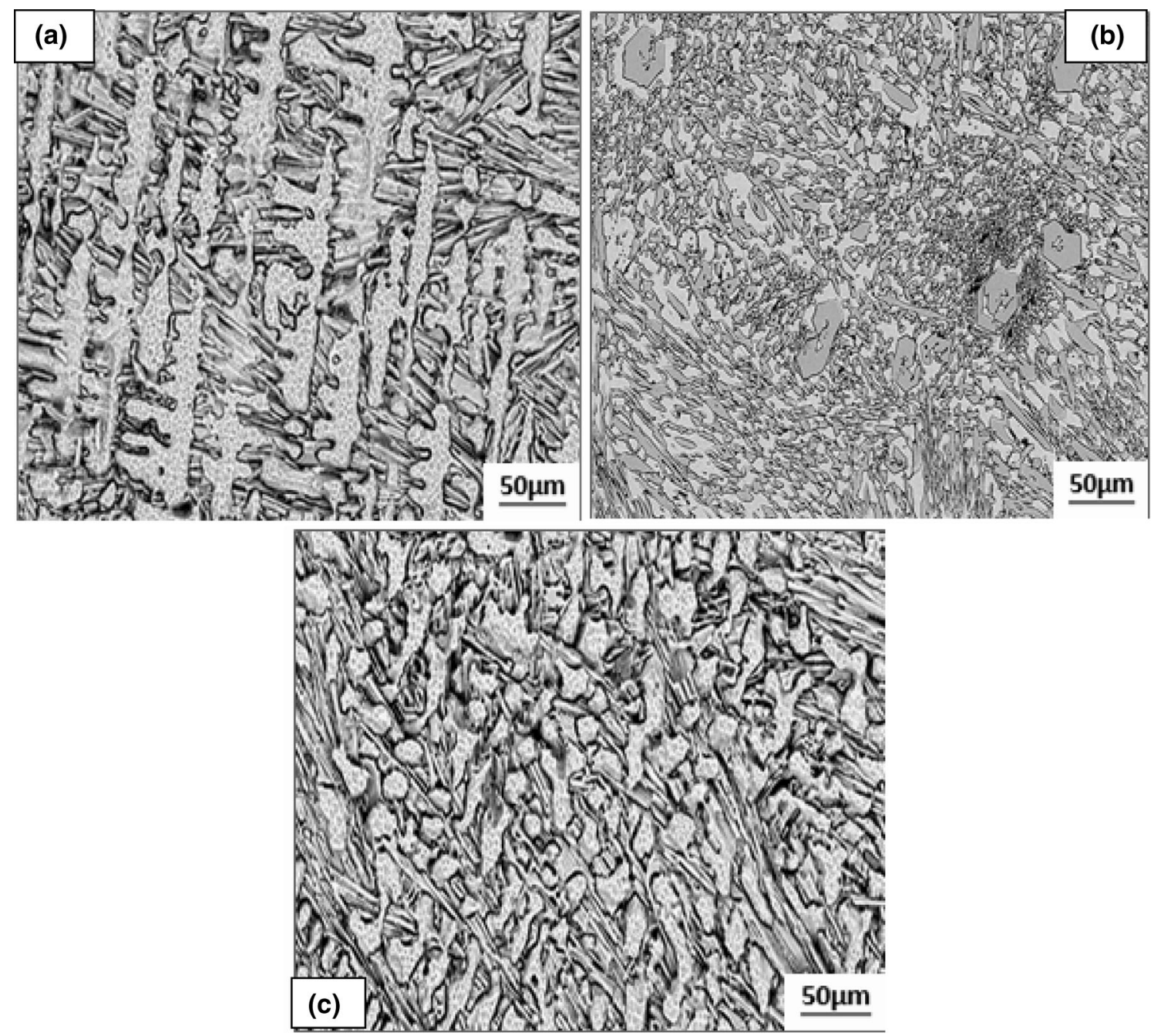

Fig. 1 SEM micrographs show the as-cast microstructure the high-Cr WCI alloys; a alloy HCCI-1 $(\mathrm{Cr} / \mathrm{C}=13), \mathbf{b}$ alloy $\mathrm{HCCI}-2(\mathrm{Cr} / \mathrm{C}=6.98)$, and $\mathbf{c}$ alloy $\mathrm{HCCI}-3(\mathrm{Cr} / \mathrm{C}=8.75)$

Fig. 2 XRD traces indicating the phases present in the as-cast microstructure of alloy HCCI-1

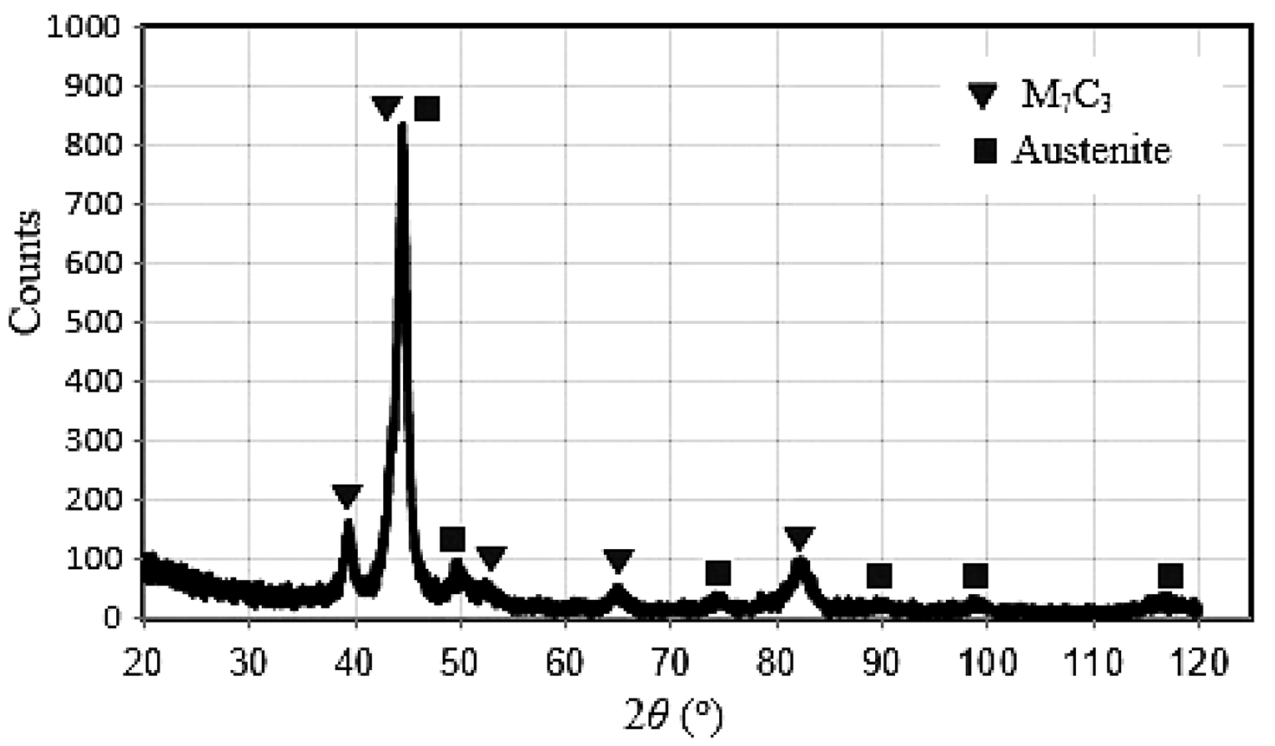



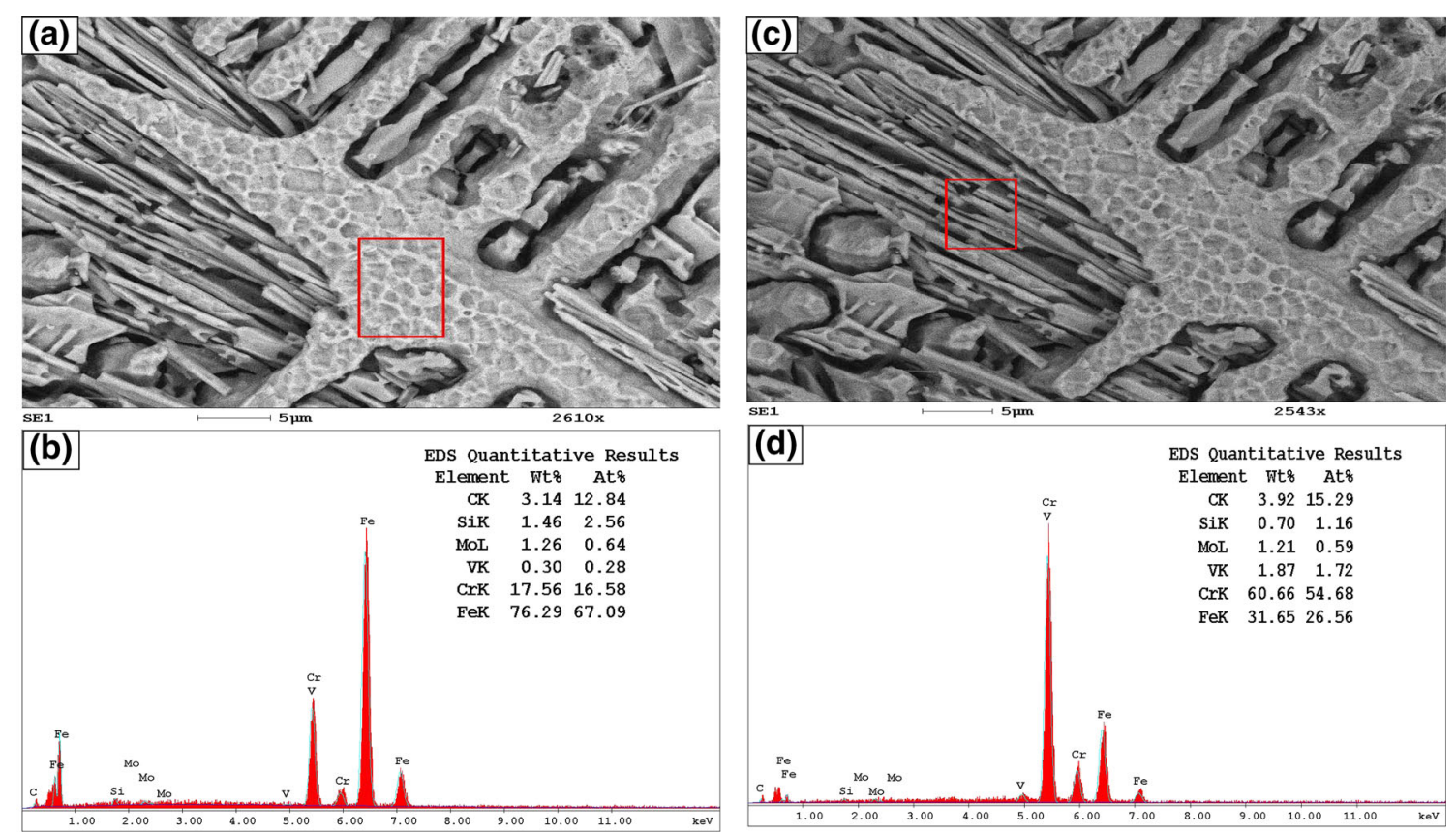

Fig. $3 \mathrm{SEM} / \mathrm{EDS}$ analysis on the as-cast microstructure of the alloy HCCI-1; a, b SEM micrograph and EDS analysis for the matrix, respectively, and c, d SEM micrograph and EDS analysis for the eutectic carbides, respectively

Fig. 4 XRD traces indicating the phases present in the as-cast microstructure of alloy HCCI-2

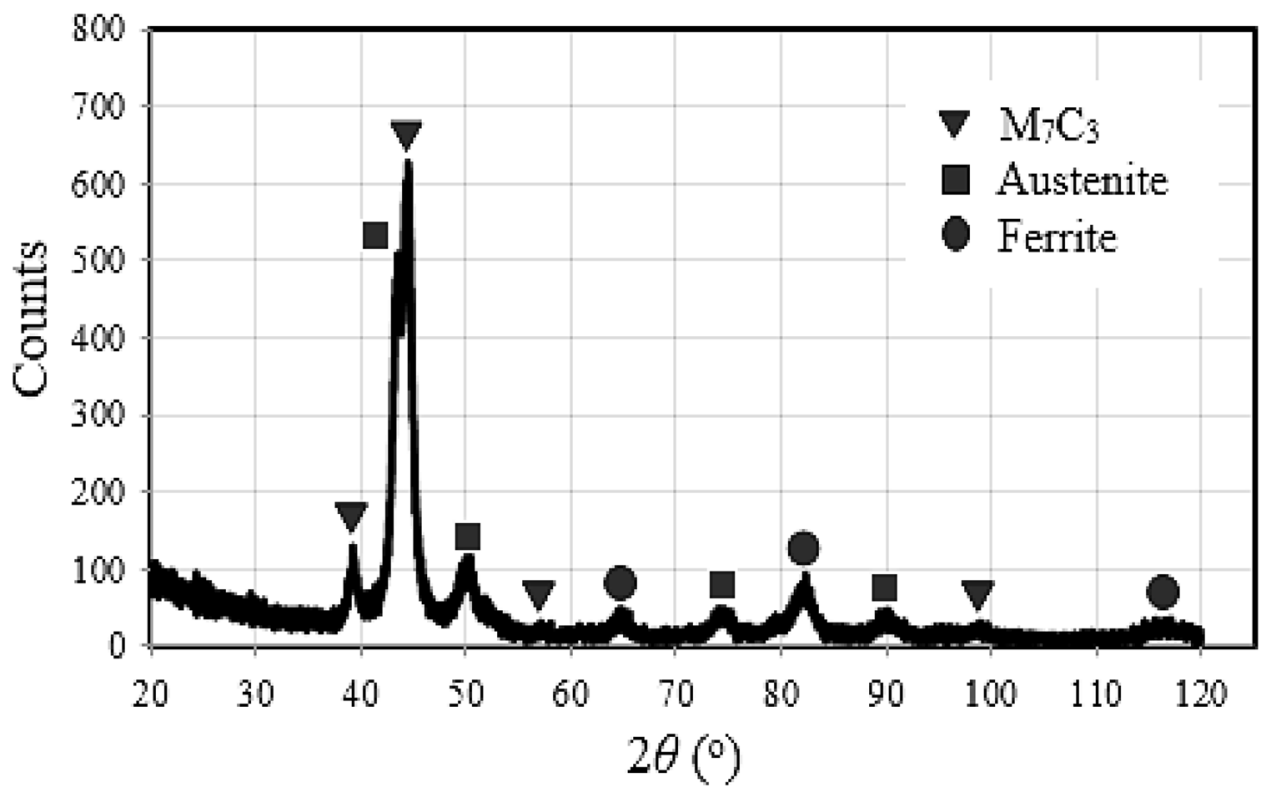



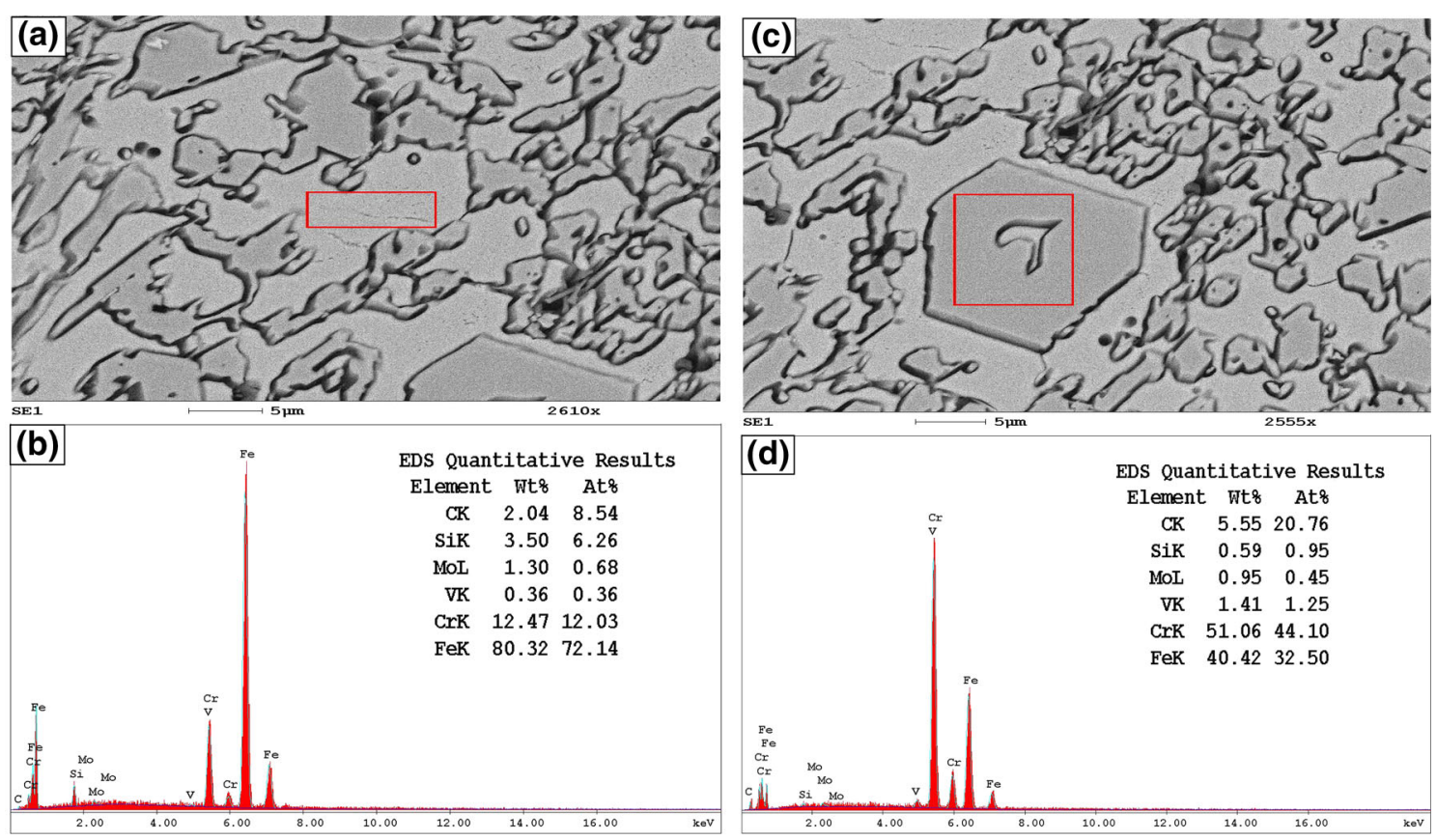

Fig. $5 \mathrm{SEM} / \mathrm{EDS}$ analysis on the as-cast microstructure of the alloy HCCI-2; a, b SEM micrograph and EDS analysis for the matrix, respectively, and c, d SEM micrograph and EDS analysis for the hexagonal-primary carbides, respectively

Table 2 Chemical point analysis of SEM-EDS (wt\%) for high-Cr WCI alloys

\begin{tabular}{|c|c|c|c|}
\hline \\
\hline \multicolumn{4}{|c|}{$\begin{array}{llll}\text { High-Cr WCI alloys }(\mathrm{Cr} / \mathrm{C}) \\
\text { wt\% element } & \text { HCCI-1 } & \text { HCCI-2 } & \text { HCCI-3 } \\
\text { (the } \mathrm{M}_{7} \mathrm{C}_{3} \text { carbides) } & (13) & (6.98) & (8.75)\end{array}$} \\
\hline \multirow{3}{*}{$\begin{array}{l}\mathrm{Cr} \\
\mathrm{Fe}\end{array}$} & 3.92 & 5.55 & 5.15 \\
\hline & 60.66 & 51.06 & 54.66 \\
\hline & 31.65 & 40.42 & 37.11 \\
\hline $\begin{array}{l}\text { wt } \% \text { element } \\
\text { (the matrix) }\end{array}$ & $\begin{array}{l}\text { HCCI-1 } \\
\text { (13) }\end{array}$ & $\begin{array}{l}\text { HCCI-2 } \\
(6.89)\end{array}$ & $\begin{array}{l}\text { HCCI-3 } \\
(8.75)\end{array}$ \\
\hline $\mathrm{C}$ & 3.14 & 2.04 & 4.11 \\
\hline \multirow{2}{*}{$\begin{array}{l}\mathrm{Cr} \\
\mathrm{Fe}\end{array}$} & 17.56 & 12.47 & 13.03 \\
\hline & 76.29 & 80.32 & 78.99 \\
\hline $\mathrm{Cr}_{\mathrm{M} 7 \mathrm{C} 3} / \mathrm{Cr}_{\text {matrix }}$ & 3.45 & 4.09 & 4.19 \\
\hline
\end{tabular}

\subsection{Abrasive Wear Behavior of the Investigated Alloys}

The effect of chemical composition, microstructure, and applied loads on abrasive wear resistance of a group of high-Cr white cast iron (HCCI) alloys with different $\mathrm{Cr} / \mathrm{C}$ ratios was investigated. In the present study, the microstructures of all HCCI alloys consist of a network of $\mathrm{M}_{7} \mathrm{C}_{3}$ eutectic carbides in an austenitic matrix as mentioned above. The presence of hard and discontinuous $\mathrm{M}_{7} \mathrm{C}_{3}$ eutectic carbides in the structure of HCCI alloys results in improving the wear resistance and toughness of these alloys. The carbide volume fraction increases with the increasing in both $\mathrm{C}$ and $\mathrm{Cr}$ contents. The abrasion resistance of the HCCI alloys increase with increasing carbide volume fraction within the structure. As estimated from Eq. (1), the volume fractions of carbides for the alloys HCCI-1, HCCI-2, and HCCI-3 was 20, 36, and $26 \%$, respectively. Figure 6 shows the relationship between the abrasive weight losses $(\mathrm{mg})$ and $\mathrm{Cr} / \mathrm{C}$ ratios of the investigated alloys at the applied loads of 20 and $40 \mathrm{~N}$ after $250 \mathrm{~m}$ total sliding distance. It is obvious from the figure that, the alloy HCCI-1 that has the lower volume fraction of carbides is the most worn alloy while the alloy HCCI-2 that has the highest volume fraction of $\mathrm{M}_{7} \mathrm{C}_{3}$ carbides is the least worn alloy and the alloy HCCI-3 exhibited an intermediate wear behavior. It is also clear that the alloy with the lowest $\mathrm{Cr} / \mathrm{C}$ ratio (i.e., $\mathrm{Cr} /$ $\mathrm{C}=6.98$ ) presents a larger volume fraction of $\mathrm{M}_{7} \mathrm{C}_{3}$ carbides providing better wear resistance. It was 
Fig. 6 The relationship between the abrasive weight loss $(\mathrm{mg})$ and $\mathrm{Cr} / \mathrm{C}$ ratios of the investigated alloys at the applied loads of 20 and $40 \mathrm{~N}$

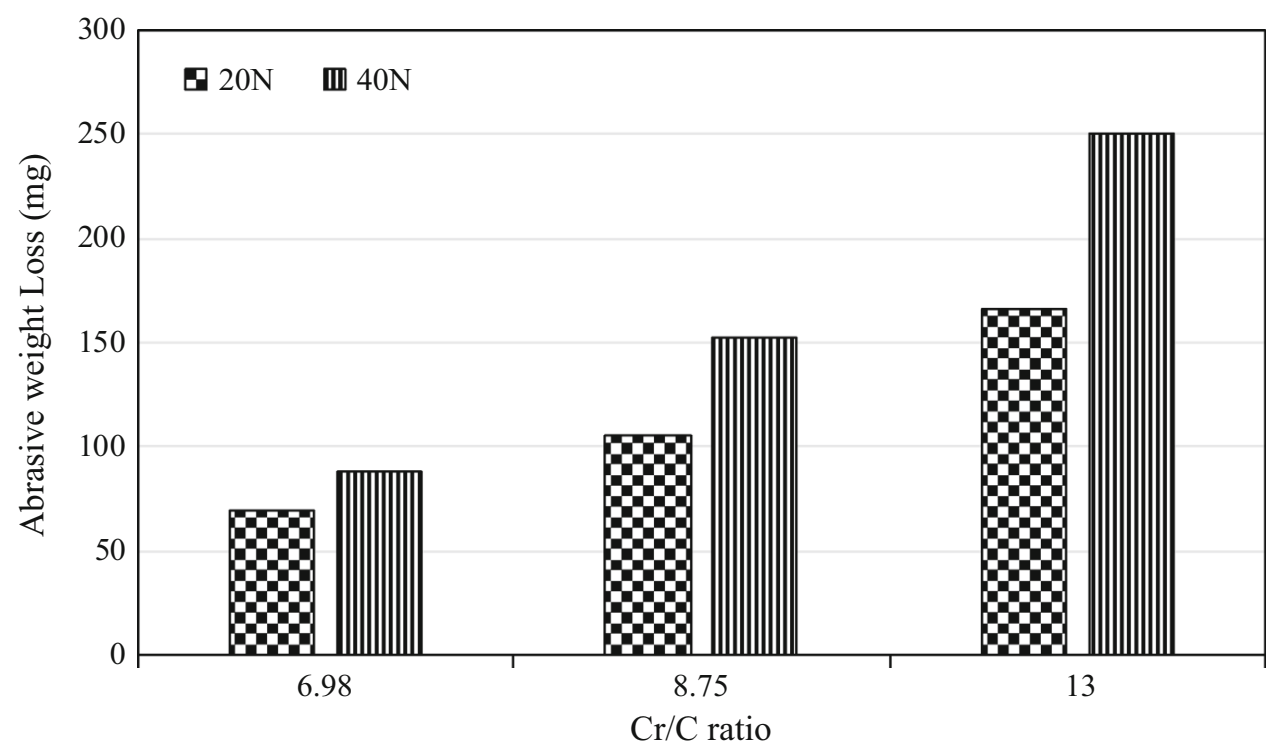

considered also that the wear behavior of these alloys is closely related to the $\mathrm{Cr} / \mathrm{C}$ ratio listed in Table 1 . According to this table, the $\mathrm{Cr} / \mathrm{C}$ ratio of the alloy HCCI-1 containing $1.8 \% \mathrm{C}$ and $24 \% \mathrm{Cr}$ is 13 while the $\mathrm{Cr} / \mathrm{C}$ ratio of the alloy HCCI-2 containing $3.16 \% \mathrm{C}$ and $23 \% \mathrm{Cr}$ is 6.98. This indicates that the abrasive wear resistance increases with a decrease in the $\mathrm{Cr} / \mathrm{C}$ ratio. This is in a good agreement with the results of Zumelzu et al. [4] and Cetinkaya [22]. They individually reported that the hardness and wear resistance of high-Cr white cast iron increased with decreasing the $\mathrm{Cr} / \mathrm{C}$ ratio. Ribeiroa et al. [19] reported that the high-chromium white cast iron alloy with a $\mathrm{Cr} / \mathrm{C}$ ratio of 6.8 exhibited the best wear resistance of the tested materials in their study. Also, the alloy HCCI-2 possess a higher volume fraction of eutectic carbides (i.e., $36 \%$ ) as mentioned before compared to that of the alloy HCCI-1. Although the presence of small amounts of Mo and V in the alloy HCCI-2 is the same as that of the alloy HCCI-1, its wear resistance was higher than that of the alloy HCCI-1 at both loads 20 and $40 \mathrm{~N}$. This is due to the presence of higher volume fraction of $\mathrm{M}_{7} \mathrm{C}_{3}$ carbides (i.e., lower $\mathrm{Cr} / \mathrm{C}$ ratio) in the alloy HCCI-2. It is obvious that the abrasive weight loss increases with increasing the test loads without any indication of occurring the work hardening particularly for the alloy HCCI-1 (with lower carbon content i.e., $1.8 \%$ ), where the highest weight loss was observed at the load of $40 \mathrm{~N}$ for all HCCI alloys. On the other hand, the ratio of wear rate of $40 \mathrm{~N}$ load to wear rate of $20 \mathrm{~N}$ load increased with increasing the $\mathrm{Cr} / \mathrm{C}$ ratio, i.e., these ratios equal $0.26,0.46$, and 0.51 for $\mathrm{Cr} / \mathrm{C}$ ratios equal $6.98,8.75$, and 13 , respectively. It is clear that, the relationship between the $\mathrm{Cr} / \mathrm{C}$ ratio, the wear rates and the loads are not linear.

\subsection{Corrosion Behavior of HCCI Alloys}

\subsubsection{The Effect of Corrosive Media on Corrosion Current Density}

The polarization curves of $\mathrm{HCCI}$ alloys in $3.5 \% \mathrm{NaCl}$ are shown in Fig. 7 with corrosion data obtained from the curves given in Table 3. The HCCI-1alloy had the lowest values for corrosion current density $\left(19.3 \mu \mathrm{A} / \mathrm{cm}^{2}\right)$ and suffered less corrosion compared to the HCCI- 2 and HCCI3 alloys. The corrosion current density of the HCCI-2 $\left(90 \mu \mathrm{A} / \mathrm{cm}^{2}\right)$ is higher than that of the HCCI-3 $(60 \mu \mathrm{A} /$ $\mathrm{cm}^{2}$ ). Moreover, the HCCI-3 recorded the most negative corrosion potential $(-754 \mathrm{mV})$, where the corrosion potential of the HCCI-1 and HCCI-2 alloys is $(-682 \mathrm{mV})$ and $(-632 \mathrm{mV})$, respectively. Figure 8 shows the polarization curves of HCCI alloys in $0.5 \mathrm{M} \mathrm{NaOH}$ and corrosion data are given in Table 3. The HCCI-2 alloy had the highest values for corrosion current density $\left(48 \mu \mathrm{A} / \mathrm{cm}^{2}\right)$ and undergo more corrosion compared to that of HCCI-1 and HCCI-3 alloys. The HCCI-1 alloy recorded a significant reduction in corrosion current density $\left(6.5 \mu \mathrm{A} / \mathrm{cm}^{2}\right)$ with the best corrosion resistance between tested alloys. Likewise, the HCCI-2 verified the most noble corrosion potential $(-240 \mathrm{mV})$, where the corrosion potential of the HCCI1 and HCCI-3 alloys is $(-251 \mathrm{mV})$ and $(-273 \mathrm{mV})$ in that order. Figure 9 displays the polarization curves of HCCI alloys in $0.5 \mathrm{M} \mathrm{H}_{2} \mathrm{SO}_{4}$ and corrosion data are recorded in Table 3. The HCCI-2alloy recorded the highest values for corrosion current density $\left(25 \times 10^{3} \mu \mathrm{A} / \mathrm{cm}^{2}\right)$ and suffered more corrosion compared to that of HCCI-1 and HCCI-3 alloys. The HCCI-1 alloy verified a major reduction in corrosion current density $\left(6.7 \times 10^{3} \mu \mathrm{A} / \mathrm{cm}^{2}\right)$ with the best 
Fig. 7 Potentiodynamic polarization curves for high-Cr WCI alloys in $3.5 \mathrm{wt} \% \mathrm{NaCl}$ solution

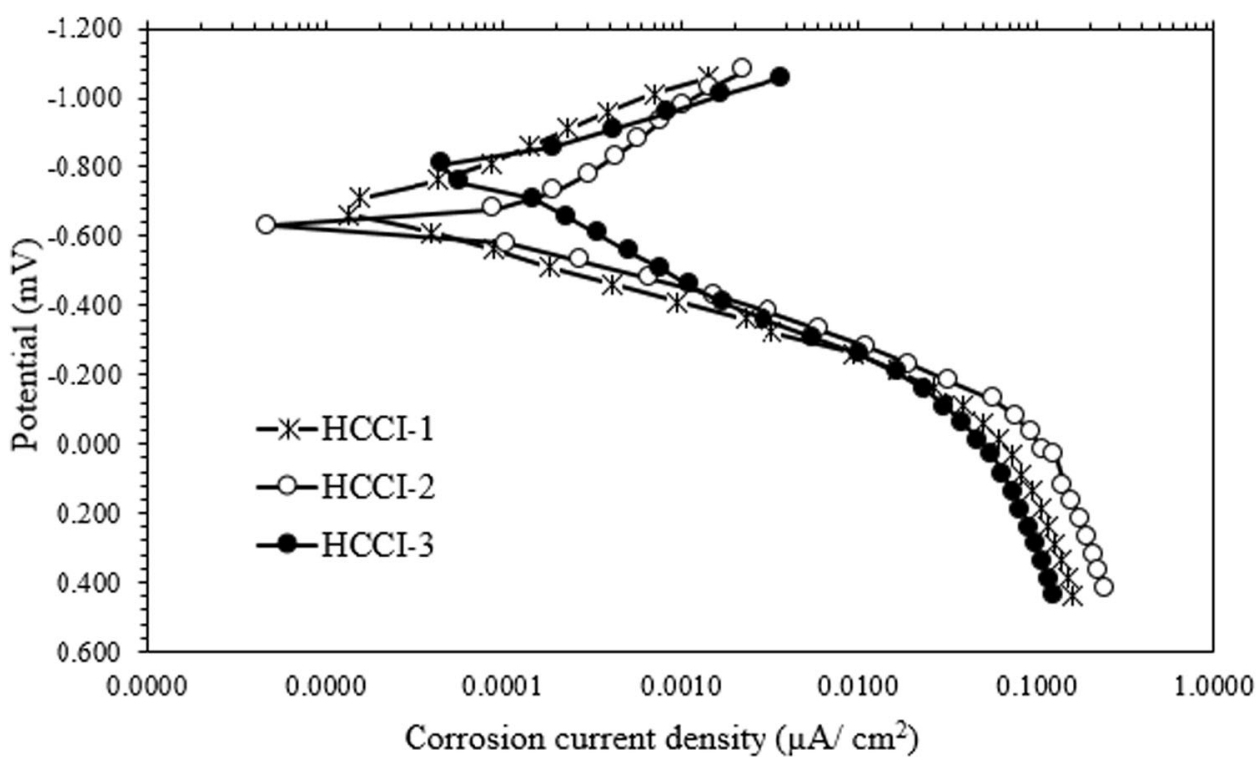

Table 3 Corrosion results of high-Cr WCI alloys in different solutions

\begin{tabular}{|c|c|c|c|c|c|c|c|}
\hline \multirow[t]{3}{*}{ Alloy designation } & \multicolumn{6}{|c|}{ Corrosive media } & \multirow[t]{3}{*}{$\mathrm{Cr} / \mathrm{C}$ ratio } \\
\hline & \multicolumn{2}{|l|}{$3.5 \% \mathrm{NaCl}$} & \multicolumn{2}{|l|}{$0.5 \mathrm{M} \mathrm{NaOH}$} & \multicolumn{2}{|l|}{$0.5 \mathrm{M} \mathrm{H}_{2} \mathrm{SO}_{4}$} & \\
\hline & $\mathrm{I}_{\text {corr }}\left(\mu \mathrm{A} / \mathrm{cm}^{2}\right)$ & $\mathrm{E}_{\text {corr }}(\mathrm{mV})$ & $\mathrm{I}_{\text {corr }}\left(\mu \mathrm{A} / \mathrm{cm}^{2}\right)$ & $\mathrm{E}_{\text {corr }}(\mathrm{mV})$ & $\mathrm{I}_{\text {corr }}\left(\mu \mathrm{A} / \mathrm{cm}^{2}\right)$ & $\mathrm{E}_{\text {corr }}(\mathrm{mV})$ & \\
\hline HCCI-1 & 19.3 & -682 & 6.5 & -251 & $6.7 \times 10^{3}$ & -412 & 13 \\
\hline HCCI-2 & 90 & -632 & 48 & -240 & $25 \times 10^{3}$ & -582 & 6.98 \\
\hline HCCI-3 & 60 & -754 & 44 & -273 & $11.6 \times 10^{3}$ & -560 & 8.75 \\
\hline
\end{tabular}

Fig. 8 Potentiodynamic polarization curves for high-Cr WCI alloys in $0.5 \mathrm{M} \mathrm{NaOH}$ solution

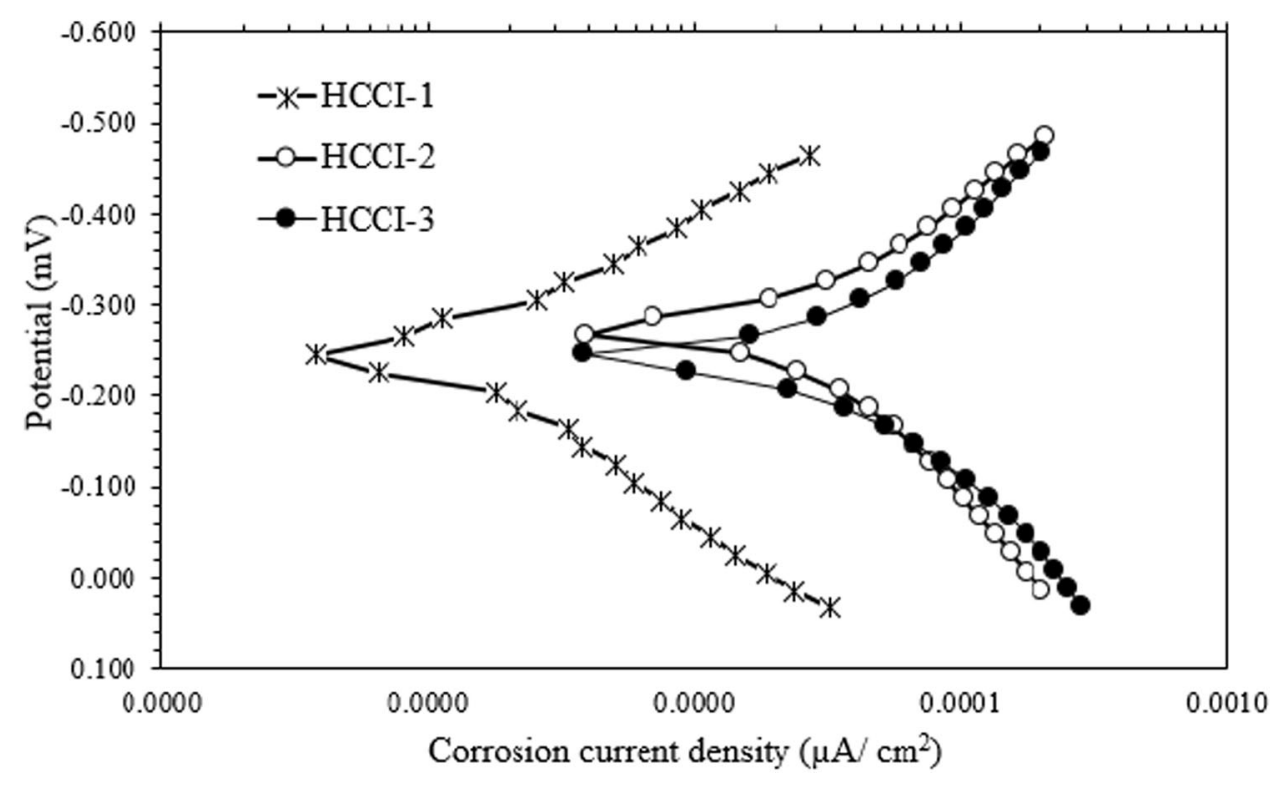

The effect of the corrosive media on corrosion current density is shown in Fig. 10. The corrosion current density of all the specimens was noticed to be strongly dependent on the corrosive media. Acidic media implies the evolution of 
Fig. 9 Potentiodynamic polarization curves for high- $\mathrm{Cr}$ WCI alloys in $0.5 \mathrm{M} \mathrm{H}_{2} \mathrm{SO}_{4}$ solution

Fig. 10 Corrosion current density $\left(i_{\text {corr }}\right)$ for the three highCr WCI alloys with different $\mathrm{Cr}$ / $\mathrm{C}$ ratios in different corrosive media $(3.5 \% \mathrm{NaCl}, 0.5 \mathrm{M}$ $\mathrm{NaOH}$, and $0.5 \mathrm{M} \mathrm{H}_{2} \mathrm{SO}_{4}$ )
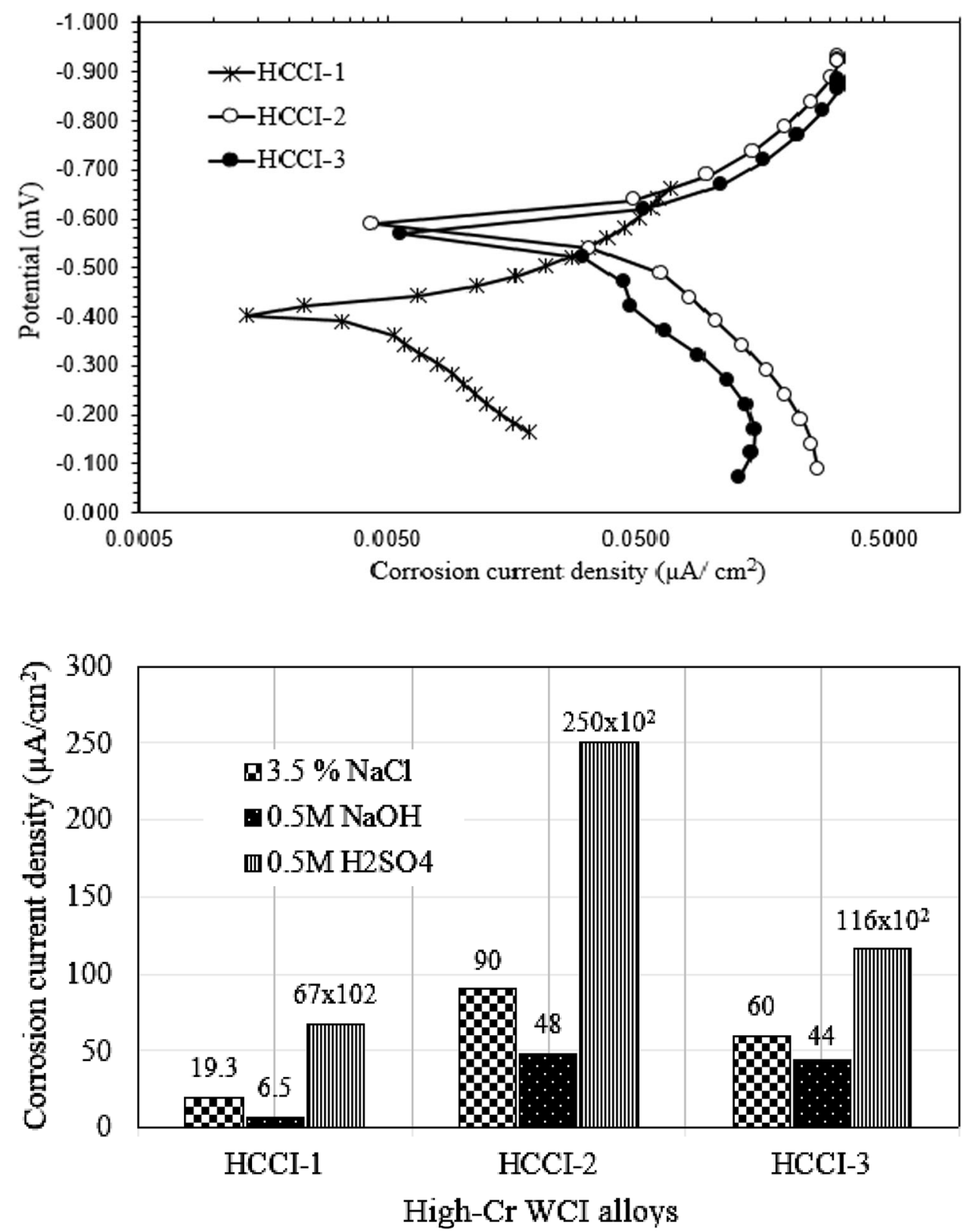

hydrogen or formation of $\mathrm{H}_{2} \mathrm{O}$ and therefore preventing the formation of any protective film. On one hand, the corrosion current density of all specimens is elevated in $0.5 \mathrm{M} \mathrm{H}_{2} \mathrm{SO}_{4}$ solution in comparison with $3.5 \mathrm{wt} \% \mathrm{NaCl}$ and $0.5 \mathrm{M}$ $\mathrm{NaOH}$ solutions. This result may due to a high rate of dissolution of the specimens in $0.5 \mathrm{M} \mathrm{H}_{2} \mathrm{SO}_{4}$ solution in comparison with other solutions. In addition, iron is a fairly active metal and can easily displace hydrogen from the mineral acid solution [23]. In acidic environment, the cathodic reaction can be described as follows:

$2 \mathrm{H}^{+}+2 \mathrm{e}^{-} \rightarrow \mathrm{H}_{2}$

In the presence of oxygen, Eq. (2) becomes:

$\mathrm{O}_{2}+4 \mathrm{H}^{+}+4 \mathrm{e}^{-} \rightarrow 2 \mathrm{H}_{2} \mathrm{O}$.
On the other hand, the decreasing in current density in both $3.5 \mathrm{wt} \% \mathrm{NaCl}$ and $0.5 \mathrm{M} \mathrm{NaOH}$ solutions attributed to the formation of an oxide layer, which stifled the corrosion process. From $\mathrm{Fe}-\mathrm{H} 2 \mathrm{O}$ potential-pH diagram [24], at $\mathrm{pH}$ above 6 , the protective scale forms in the form of $\mathrm{Fe}(\mathrm{OH}) 2 /$ $\mathrm{Fe}(\mathrm{OH}) 3$ which hinder mass transport of oxygen and ionic species in the solution [25].

\subsubsection{The Relationship Between the Microstructure and Corrosion Behavior}

The cast iron which was studied consisted of multiphase structure consisting of $\mathrm{M}_{7} \mathrm{C}_{3}$ carbides in a matrix of austnite and ferrite phases. It is assumed that there is no setup 

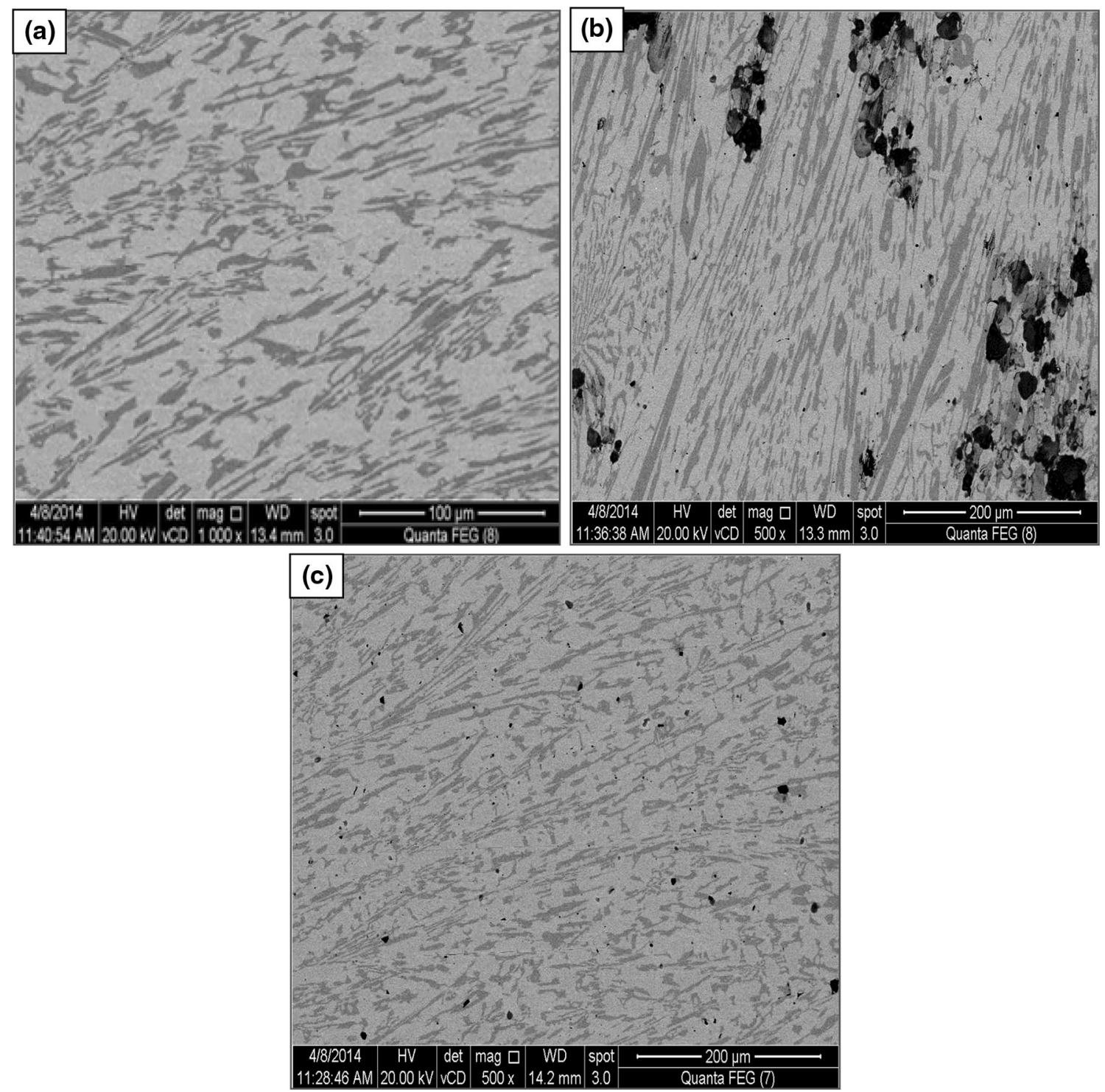

Fig. 11 SEM micrographs after potentiodynamic corrosion tests in $0.5 \mathrm{M} \mathrm{NaOH}$ solution show the corroded surfaces of; $\mathbf{a}$ alloy HCCI-1, b alloy HCCI- 2 and c alloy HCCI-3

of electrolytic cell between the phases, the following reactions are possible: the anodic reactions in ferrite and cementite are respectively:

$$
\begin{aligned}
& \mathrm{Fe} \rightarrow \mathrm{Fe}_{2}^{+}+2 \mathrm{e}^{-} \\
& \mathrm{Fe}_{3} \mathrm{C} \rightarrow 3 \mathrm{Fe}_{2}^{+}+\mathrm{C}+6 \mathrm{e}^{-}
\end{aligned}
$$

The cathodic reaction in acidic solution could be described by Eq. (3). In neutral and alkaline solution, the cathodic reaction could be described as follows:

$$
\mathrm{O}_{2}+\mathrm{H}_{2} \mathrm{O}+4 \mathrm{e}^{-} \rightarrow 4 \mathrm{OH}^{-} \text {. }
$$

The volume fractions of the phases in the microstructure have been calculated and presented earlier under Sect. 3.1. It showed that the higher volume fraction of carbides was
$36 \%$ for the HCCI-2 alloy and the lower volume fraction was $20.5 \%$ for the HCCI-1 alloy. It can be generally concluded that the HCCI-1 alloy $(\mathrm{Cr} / \mathrm{C}=13)$ gave considerable improvement in corrosion resistance over the HCCI-2 $(\mathrm{Cr} / \mathrm{C}=6.98)$ and HCCI-3 $(\mathrm{Cr} / \mathrm{C}=8.75)$ alloys. The corrosion resistance of HCCI alloys mainly depends on the chemical composition of the ferrous matrix, mainly the concentration of free $\mathrm{Cr}$ in matrix, which increases the corrosion resistance of HCCI alloys [8, 14].The high or ultra-high level of chromium and other elements in these alloys result moderate to outstanding corrosion resistance in relatively severe corrosive conditions. $\mathrm{Cr}$ is a crucial element for corrosion resistance of white cast irons. Higher $\mathrm{Cr}$ content is needed at relatively high corrosion intensity 

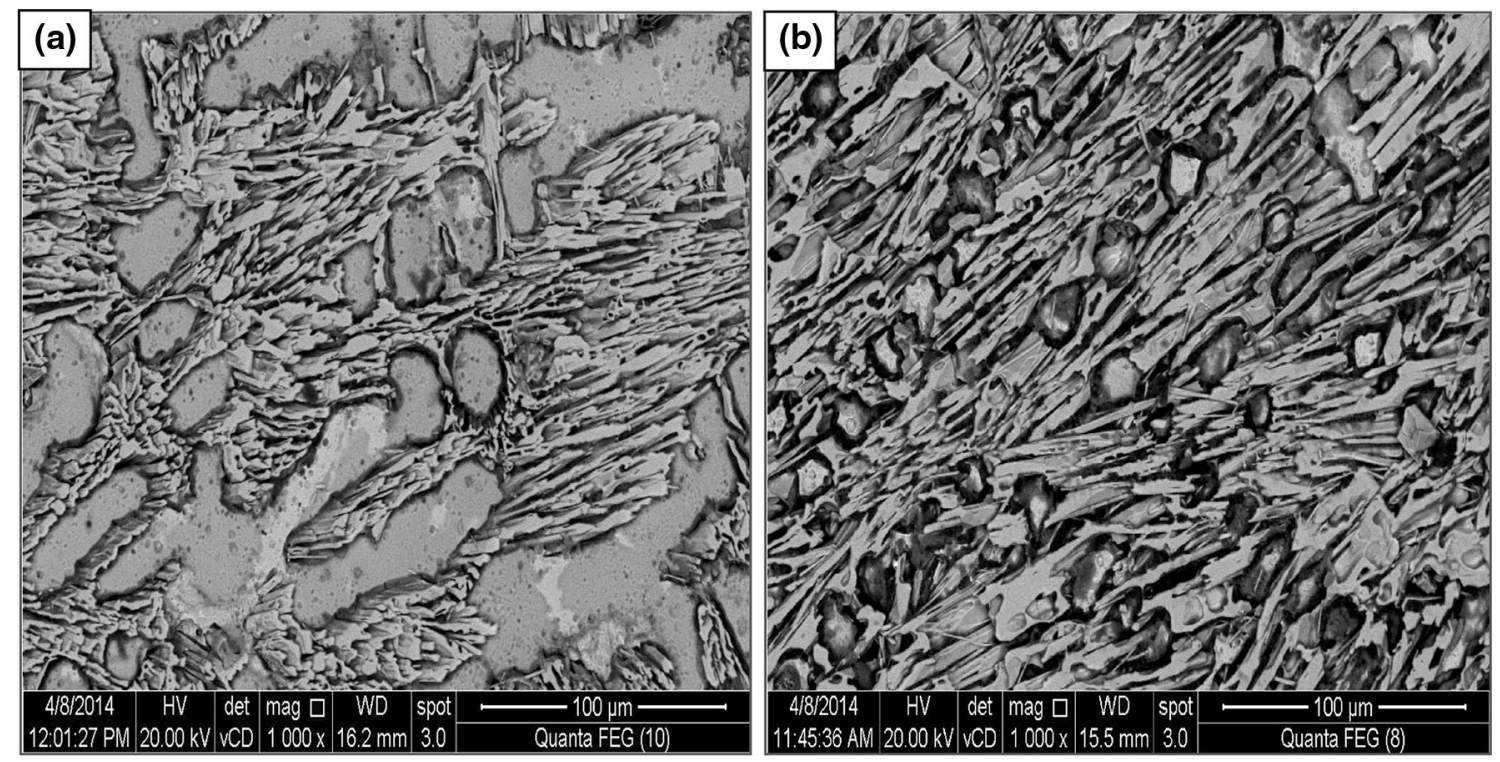

Fig. 12 SEM micrographs after potentiodynamic corrosion tests in $0.5 \mathrm{M} \mathrm{H}_{2} \mathrm{SO}_{4}$ solution show the corroded surfaces of; a alloy $\mathrm{HCCI}-1$ and b alloy HCCI-2

to promote passivation and to overcome the depletion effect especially at the interface areas between the matrix and carbides. With an increase in $\% \mathrm{C}, \mathrm{Cr}$ concentrations in the ferrous matrix decreased accompanied with the formation of more carbides, therefore, $\mathrm{Cr} / \mathrm{C}$ ratio is as a main contributor for corrosion resistance. As the $\mathrm{Cr} / \mathrm{C}$ ratio increases, the difference between the $\mathrm{Cr}$ content in the eutectic carbide and that of in the matrix, described as $\mathrm{Cr}$ partition ratio in Table 2, decreased from 4.19 for the HCCI-3 alloy to 4.09 and 3.45 for the HCCI- 2 and HCCI-1 alloys, respectively. The observed reduction in corrosion current density with increasing $\mathrm{Cr} / \mathrm{C}$ ratio is in an agreement with the findings of the previous studies $[4,9,26]$.

\subsubsection{The Microstructure After Corrosion}

The corroded surfaces of the alloys HCCI-1, HCCI-2, and HCCI-3 after polarization test in $0.5 \mathrm{M} \mathrm{NaOH}$ solution are shown in Fig. 11a-c. Figure 11a shows the corroded surface of the alloy HCCI- 1 that has the best corrosion resistance as discussed above. From this figure, it is obvious that the corrosion of the alloy HCCI- 1 is a uniform corrosive damage. Beimeng et al. [27] reported that, the homogeneous structure without obvious cracks or pits is an evidence of the high corrosion resistance of cast iron alloys. As indicated in Fig. 11b, the alloy HCCI-2 suffered from more localized corrosion than that of the alloy HCCI3 shown in Fig. 11c. This is due to the regions closed to the eutectic carbides were depleted in $\mathrm{Cr}$ leading to attack those of the matrix adjacent to the eutectic carbides, whereas in HCCI-3 alloy the higher $\mathrm{Cr}$ content in the dendritic austenite providing greater protection [28]. Figure $12 \mathrm{a}, \mathrm{b}$ shows that corrosion attack (dark color) and the pits in the eutectic matrix are generally more prevalent in $0.5 \mathrm{M} \mathrm{H}_{2} \mathrm{SO}_{4}$ solution than in $0.5 \mathrm{M} \mathrm{NaOH}$ solution. It is quite clear that corrosion attack is initiated around the $\mathrm{M}_{7} \mathrm{C}_{3}$ primary carbides, as illustrated in Fig. 12a, b, where black lines are observed surrounding the carbides. The black lines occur in the element depleted region (e.g., $\mathrm{Cr}$ ) that envelopes chromium-rich zones in the bulk carbide. Therefore, the corrosion attack at this site can be caused by three factors: microgalvanic interaction between two regions, simply chromium depletion leading over corrosion resistance, and microcrevice attack [29].

\section{Conclusions}

The abrasive wear and corrosion behavior of a group of HCCI alloys with different $\mathrm{Cr} / \mathrm{C}$ ratios were investigated. The main conclusions obtained from this study are as follows:

1. XRD analysis reveals that the microstructure of the HCCI alloys is composed of a network of chromiumrich carbides $\left(\mathrm{M}_{7} \mathrm{C}_{3}\right)$ in austenitic matrix. The higher $\mathrm{Cr} / \mathrm{C}$ ratio with small Mo content (i.e., 0.5\%) promoted austenitic matrix microstructure rather than pearlitic one.

2. Abrasive wear resistance of HCCI alloys was found to be rely on their chemical composition and microstructure. The alloy HCCI-2 with lower $\mathrm{Cr} / \mathrm{C}$ ratio exhibited the lowest abrasive weight loss while the alloy HCCI-1 
with higher $\mathrm{Cr} / \mathrm{C}$ ratio exhibited the highest abrasive weight loss under the loads of 20 and $45 \mathrm{~N}$.

3. The corrosion behavior of the HCCI alloys is controlled by their matrix, since the hard phases (i.e., $\mathrm{M}_{7} \mathrm{C}_{3}$ carbides) show an inert behavior during anodic polarization.

4. The corrosion resistance of the HCCI alloys strongly depends on $\mathrm{Cr} / \mathrm{C}$ ratio and the ratio of chromium content in the $\mathrm{M}_{7} \mathrm{C}_{3}$ carbide to that of in the matrix $\left(\mathrm{CrM}_{7} \mathrm{C}_{3} /\right.$ Matrix $)$. The $\mathrm{Cr}$ content in eutectic carbides and matrix increased proportional to the overall $\mathrm{Cr}$ content of the alloys.

5. The HCCI-1 alloy, which has the highest $\mathrm{Cr} / \mathrm{C}$ ratio, was the most corrosion resistant one otherwise the $\mathrm{HCCI}-2$ alloy with the lowest $\mathrm{Cr} / \mathrm{C}$ ratio was of a poor corrosion resistance.

6. The corrosion current density of all specimens is elevated in $0.5 \mathrm{M} \mathrm{H}_{2} \mathrm{SO}_{4}$ solution in comparison to 3.5 wt $\% \mathrm{NaCl}$ and $0.5 \mathrm{M} \mathrm{NaOH}$ solutions.

\section{References}

1. Abd El-Aziz Kh, Saber D, Sallam HEM (2015) Wear and corrosion behavior of Al-Si matrix composite reinforced with alumina. J Bio Tribo Corros 1:5

2. Pearce JTH (2002) High-chromium cast irons to resist abrasive wear. Foundryman 95(4):156-166

3. Karantzalis AE, Lekatou A, Mavros H (2009) Microstructural modifications of As-cast high-chromium white iron by heat treatment. ASM Int JMEPEG 18:174-181

4. Zumelzu E, Goyosb I, Cabezas C, Opitz O, Parad A (2002) Wear and corrosion behaviour of high-chromium (14-30\% $\mathrm{Cr}$ ) cast iron alloys. J Mater Process Technol 128:250-255

5. Sallam HEM, Abd El-Aziz Kh, Abd El-Raouf H, Elbanna EM (2013) Flexural strengthand toughness of austenitic stainless steel reinforced high-Cr white cast ironcomposite. J Mater Eng Perform 22(12):3777

6. Sallam HEM, Abd El-Aziz Kh, Abd El-Raouf H, Elbanna EM (2013) Failure analysis and flexural behavior of high chromium white cast iron and AISI4140 Steel bimetal beams. Mater Des 52:974-980

7. Berkeley DW, Sallam HEM, Nayeb-Hashemi H (1998) The effect of $\mathrm{pH}$ on the mechanism of corrosion and stress corrosion and degradation of mechanical properties of AA6061 and Nextel 440 fiber reinforced AA6061 composite. Corros Sci 40:141

8. Tanga XH, Chunga R, Panga CJ, Li DY, Hinckleyb B, Dolmanb K (2011) Microstructure of high (45 wt\%) chromium cast irons and their resistances to wear and corrosion. Wear 271:1426-1431

9. Tian HH, Addie GR, Visintainer RJ (2009) Erosion-corrosion performance of high-Cr cast iron alloys in flowing liquid-solid slurries. Wear 267:2039-2047
10. Sain PK, Sharma CP, Bhargava AK (2012) Microstructure aspects of a newly developed, low cost, corrosion-resistant white cast iron. Metall Mater Trans A 44:1665-1672

11. Huang X (2001) The effect of Mo on the structure of high Cr-Mo alloy iron. J Mater Eng Perform 10(5):592-595

12. Powell G, Randle V (1997) The effect of Si on the relation between orientation and carbide morphology in high chromium white irons. J Mater Sci 32:56

13. Karantzalis AE, Lekatou A, Kapoglou A, Mavros H, Dracopoulos V (2012) Phase transformations and microstructural observations during subcritical heat treatments of a high-chromium cast iron. ASM Int J Mater Eng Perform 21(6):1030-1039

14. Wiengmoon A, Pearce JTH, Chairuangsri T (2011) Relationship between microstructure, hardness and corrosion resistance in $20 \mathrm{wt} \% \mathrm{Cr}, 27 \mathrm{wt} \% \mathrm{Cr}$ and $36 \mathrm{wt} \% \mathrm{Cr}$ high chromium cast irons. Mater Chem Phys 125:739-748

15. Gundlach RB, Doane DV (1991) Heat treating of high alloy irons, ASM hand book, heat treating, vol 4, 4th edn. ASM International, Almere, pp 697-708

16. Carpenter SD, Carpenter D, Pearce JTH (2004) XRD and electron microscope study of an As-cast $26.6 \%$ chromium white iron microstructure. Mater Chem Phys 85:32-40

17. Sare IR, Arnold BK (1995) The Effect of heat Treatment on the gouging abrasion resistance of alloy white cast irons. Metall Mater Trans A 26A:357

18. Tabrett CP, Sare IR, Ghomashchi MR (1996) Microstructureproperty relationships in high chromium white iron alloys. Int Mater Rev 41(2):52-89

19. Ribeiroa L, Barbosab A, Vianaa F, Monteiro Baptistac A, Diasd C, Ribeiroa CA (2011) Abrasion wear behaviour of alloyed and chilled cast irons. Wear 270:535-540

20. Tabrett CP, Sare IR (1997) The effect of heat treatment on the abrasion resistance of alloy white irons. Wear 203-204:206-219

21. Maratray F, Usseglio-Nanot R (1971) Atlas-transformation characteristics of chromium and chromium-molybdenum white iron. Climax Molybdenum S.A. Paris, Paris

22. Cetinkaya C (2006) An investigation of the wear behaviour of white cast irons under different compositions. Mater Des 27:437-445

23. Andrews Anthony, Kwofie Samuel (2010) Corrosion of cast iron mill plates in wet grinding. J Pract Technol 17:97-108

24. Roberge PR (1999) Handbook of corrosion engineering. McGraw-Hill, New York

25. Stachowiak G, Salasi M, Stachowiak G (2015) Three-body abrasion corrosion studies of high-Cr Cast irons: benefits and limitations of tribo-electrochemical methods. J Bio Tribo Corros. $1: 6$

26. Tanga XH, Chunga R, Li DY, Hinckleyb B, Dolmanb K (2009) Variations in microstructure of high chromium cast irons and resultant changes in resistance to wear, corrosion and corrosive wear. Wear 267:116-121

27. Beimeng Q, Beijia W, Chenguang W, Yixing Y (2013) Electrochemical behavior of cast iron in the presence of bacteria in water distribution systems. Int J Electrochem Sci 8:1813-1821

28. Poolthong N, Nomura H, Takita M (2004) Effect of heat treatment on microstructure and properties of semi-solid chromium cast iron. Mater Trans 45:880-887

29. Neville A, Reza F, Chiovelli S, Revega T (2006) Characterization and corrosion behavior of high-chromium white cast irons. Metall Mater Trans A 37:2339-2347 